\title{
Mentoring the Student-Teacher on School Records and Record Keeping for Effective Teaching Practice Exercise in Nigeria
}

\author{
WALI, WORLU I. (Ph.d) \\ Department of Educational Management, Faculty of Education \\ Ignatius Ajuru University of Education, Port Harcourt
}

\begin{abstract}
In every professions, there are period for internship. Teaching profession is not left out. The student-teacher goes out for teaching practice for a specific period of time under the supervision of more experienced teachers. Among what is expected for the student-teacher to know is school records and record keeping. It is on this regards that this paper hinged on mentoring, the student-teacher on school records and record keeping for effective teaching practice exercise in Nigeria. To this effect, the paper addressed the meaning of school records and recording keeping, types of records kept in schools, importance of school records, the type of records to be kept by student-teacher, mentoring student-teachers on how to enter some records. The paper concluded that student-teacher should practically know and keep record which was theoretically taught in the mother institution. The paper recommended, among other, colleges of education, faculty of education should integrate record keeping as part of teaching practice practicum just as micro-teaching, school records and record keeping should be form part of the things required to be supervised when their supervisor visit them, the school head of studentteacher positing should organize orientation/induction programme for the student-teacher and student-teacher should be included in Student Industrial Work Experiences Scheme(SIWES)
\end{abstract}

Keywords: School records, keeping, student-teacher mentoring, teaching practice.

DOI: $10.7176 / \mathrm{JEP} / 10-18-13$

Publication date:June $30^{\text {th }} 2019$

\section{Introduction}

Student- Teachers also called trainee teachers are those students of higher learning who are undergoing teaching practice exercise in schools, who are posted to such schools by their parents institutions- Faculties of Education of Universities Colleges or Colleges of education. During the teaching practice exercise, the student- teachers are given the opportunity to integrate different types of knowledge and use them in specific school contexts. Teaching practice is thus the period of time in which student-teachers gains firsthand experience teaching. Stone and Moris in Ogina-Obu (2009) explains teaching practice exercise as:

$>$ The practicing of teaching skills and the acquisition of the role of the teacher

$>$ The whole range of experiences that students go through in schools; and

$>$ The practical aspects of the course as distinct from the mere theoretical studies of teacher training

In similar way, Ezewu, Okoye and Onyekwelu (1984) were of the views that teaching practice is expected to help student teachers by:

$>$ Exposing them to the classroom and school situations, the knowledge of which will enable them on graduation to be fully aware of what they are going to meet in school

$>$ Enable them to put into practice; the psychological and sociological principles they have learnt to maintain proper classroom atmosphere suitable for teaching and learning; and the principles of methods of teaching various subjects.

$>$ To enable them to come into contact with young persons, the type they would meet and teach on graduation so that this period becomes one of rehearsal in handling young people.

$>$ Enabling them to come into contact with school of practice teaching so that experiences gained during this period will help on graduation

Also worthy of note is that during the period of teaching practice exercise, the student-teachers are expected to observe the entire work of the school and participate actively in all the important professional activities of a teacher, including record keeping, both in and out of classroom . but it is unfortunate that a good number of the students teachers scarcely know how school records are kept. Infact, some of them go through the teaching practice exercise, without knowing how to mark class attendance register, enter the lessons taught in the diary and other important school records as well as take part in other school in door or out-door activities. It is on this premise that this chapter anchores on mentoring the student -teacher on school records and record keeping for effective teaching practice exercise in Nigeria.

To achieve this, the paper looked at the

$>$ Definition of school records and record keeping,

$>$ type of records kept in schools,

$>$ importance of school records, 
$>$ the type of records to be kept by student- teachers; and

$>$ how to enter school diary, scheme of work, attendance register, etc,

$>$ meaning and importance of extra-curriculum activities

\section{Definition of School Record and Record Keeping}

Record, according to Hornby (2014) is a written account of something that is kept so that it can be looked at and used in the future. Asogwu (2004) defined records as relating to data or documents generated in the course of execution of legitimate functions of an organization. The above explains that record could be on paper, in firms, tape, record disc, on a video cassette, diskette or computer.

From the above definition of record, it could be deduced that school records are the information bank of the school that are written or stored on paper, file, film, tape, disc, video, diskette or computer which are retrievable when the need arises. Bosah in Ndu, Ocho and Okeke (1997) sees school records as documented statements of facts about persons, facilities, proposals and activities in and about the school. Ochai (2012) defined school records as an official documents, books and files containing crucial information of actions and events which are kept and preserved in school office for retrieval and utilization when needed. In the same vein, Ogbonnaya in Ogbonnaya (2013) defined school records as all the books and files containing information relating to what goes on in the school, who is in the school as well as what types of property the school wants. Ogbonnaya further defines record keeping as the efficient storage and retrieval of information when needed. Umeji and Obi(2013) defined record keeping as the making and maintaining of complete, accurate and reliable evidence of transaction in the form of recorded information.

The above definitions showcased that record keeping is an indispensable responsibility of the school administration. The school administrator and those working under him, including student-teacher, are expected to honestly and faithfully keep accurate school records.

\section{Types of records kept in School}

There are different types of record kept in schools. however, Wali (2007) classified school records that could be kept in schools into statutory and non-statutory records. According to him, the statutory records are those prescribed by education law or edict or decree which must be kept in all schools and produced on the demand by those who are in authorities, and non-statutory records are those that are not compulsorily kept but are necessary and voluntarily kept by the school head to guide him/her in the day-to-day administration of the school. Wali (2007) went further to enumerate the records to be kept in Nigeria schools as follows:-

$>$ Register of admission, progress and withdrawal

$>$ Class attendance register and fees

$>$ Log book

$>$ School time table

$>$ Weekly diaries

$>$ Visitors book

$>$ Conduct book (punishment book)

$>$ Records of students academic performance

$>$ School inventory book (stock book)

$>$ Syllabus

$>$ Lesson notes and plans

$>$ Cash records/ledger

$>$ School budget

$>$ School imprest account

$>$ National policy on Education

$>$ Transfer and leaving certificate

$>$ Teacher service manual

$>$ Records of building and physical development

$>$ Staff attendance book

$>$ Minutes of meetings

$>$ Duty roaster and report book

$>$ Student personal hygiene record

$>$ Record of health of pupils/students

$>$ Staff record

$>$ Movement book

$>$ Teachers' class attendance register

$>$ Records of club/society activities

$>$ Records of ex-students 
Inspection/supervision report book or file

$>$ Records of games and sporting activities

The following school records kept by schools could be added here:

$>$ Correspondence file

$>$ Handing over/taking over notes

$>$ Write-off authority note

$>$ Announcement book

$>$ PTA meeting files

$>$ Garden and farms record

$>$ Boarding records

\section{Importance of Record Keeping in Schools}

Record keeping in schools are important to School Head and Ministry of Education or any other stockholder because it provides:

$>$ a good source of school history;

$>$ great assistance for successive school heads in the challenging task of school management;

$>$ useful information on staff and students

$>$ information on important school activities

$>$ veritable sources of information for referencing staff and students of the school when the need arises;

$>$ data bank for educational planners in making future projections

$>$ empirical base for assessing school academic performance;

$>$ a useful guide for school inspection and supervision (Onwurah in Mgbodile, 2004; and Wali, 2007).

\section{Types of Records to be kept by student-Teachers}

The Student - Teachers, like the "Traditional Teachers" has records to keep during their stay on teaching practice exercise. The must unfortunate thing is that some of these records are neither seen nor used by them. Nevertheless, school records that could be kept by student-teachers are explained below:-

\section{National Policy on Education}

This is a policy document containing the summary of the nation's objectives, educational philosophy, goals and objectives. It spells out the ends to be realized at each level and type of education and prescribe how those ends are to be achieved or realized. Every student teacher should ensure that he/she has a copy of this document. This policy document helps in sharpening the perception of the student-teacher on what the objectives of the school should be and know the instructional materials that should be used to achieve the said objectives. It also provides a check on how far a student teacher can go in making innovations in the classroom.

\section{Syllabus}

Syllabus is a record which shows subject by subject, topic by topic to be taught and the indept at which each topic should be treated. Agunwa (1986) sees syllabus as a body of knowledge prescribed to be covered for given subjects during a specific course of instruction. Syllabus are usually prepared by experts from Ministry of Education for those in Basic Education and West African Examination Council (WAEC) and National Examination Council (NECO) for those in senior secondary schools. The preparation covers in each of the subject areas the detail description of what is expected to cover. Therefore, every school head should procure a copy of the current syllabus for reference and student- teachers are expected to borrow it for perusal.

\section{Record of student Test and Assignment}

Record of test and assignment are an indispensable record that student-teachers must keep. It is the record of scores of test and assignment which the student - teacher gives to the students of his class based on the subject taught to determine the students level of preparedness, understanding and performance. The test and assignment scores are handed over to subject teacher to form part of continuous assessment. In this record, column for serial numbers, name of the students, students admission numbers, test scores, assignment scores, total mark scored, average and remarks or students position are provided.

\section{Weekly Diary}

The weekly diary is derived from the syllabus. It is made up of scheme of work and record of work done in each subject every week. Provisions are made for revision of work done in a term. This helps in preparing students for examination. Usually the entries are made by the subject teacher who signs and submits it for supervision by the school head at the end of every week.

The record of work is complimentary to the scheme of work. It is a record of work done against work 
proposed. Put differently, record of work shows work that is already done. It is therefore unethical or unprofessional for a teacher to record as covered, topics which have not been taught in the class for this is misleading and not to the interest of the students in case a new teacher is assigned to that class. Moreso, examinations questions are usually drawn from the record of work and the students are at a disadvantage if they are tested on what they did not study.

Nevertheless, the weekly diary provides for teaching accountability, it makes for easy identification of dedicated and lousy student- teachers. It helps the student teacher who is assigned to a class to take off. It also guide student-teachers in setting test and examination questions, which should be based only on the work covered.

\section{Student-Teacher Attendance Book}

This is also called "time book". It is a book the student- teachers indicate how punctual and regular they were to school. In this book, there are columns provided for data, serial number, name of student-teacher, time in, signature, time out, signature and remark.

This book helps their supervisors and school head in checking truancy, punctuality and duration of a student teacher stay in the school for each school day.

\section{Student-Teachers' class Attendance Register}

This is somethings called "Record of First Instance". It is usually kept with the class monitors/prefects. In this register the class monitor/prefect indicates the name of the student teacher, teaching period/time, punctuality, actual teaching, subject taught, completion of period and remark. This register is submitted to the school head at the end of the week by the monitor/prefect. This may be given to student-teachers' supervisors for perusal on demand.

\section{Lesson Note and Plans}

Lesson note is the student-teacher's guide as he delivers his/her lesson. The student teacher drawn it from scheme of work, just as scheme of work is drawn from syllabus. It is prepared on daily basis. It is expected that every student- teacher should write out what they are going to teach in the lesson note/plan and provide them on the demand of the school head or supervisors. A good lesson note contains the week, class sex, subject title, topic, date, time duration, specific objectives/behahaviour objectives/performance objectives, entry behavior/previous knowledge, set induction, instructional procedures/development evaluation/backboard/chalkboard/white board summary, and assignment.

\section{Time Table}

Time table is the heart beat of every school, because it ensures that the school curriculum is implemented with proportional attention given to all subjects and activities. (1990) refers to time table is an outlay or list of days and hours at which specific events are to take place, or when particular piece of work is to be done.

School time table therefore is the programmed chart in a piece of paper which shows every subject taught in the school and in all the classes throughout the week. It regulates the progress of activities, dictating when classes begins, where break is to occur, and when the day's work is to end. It shows the time and the lessons for each day of the week and the teachers to teach them.

Student teachers have to make extracts of what lessons they are to teach, and at what times, and keep so that they know when to go for their lessons.

\section{Duty Roaster and Report Book}

Duty roaster is the list of teachers' and prefects' names who are assigned to monitor all activities in the school for a period of one week. Therefore, the teacher, student-teacher and the prefect on duty for the week need to record their activities and challenges encountered within the week in the report book. The report book will serve as a guide to teacher, student-teachers and prefects who will be on duty in the future weeks. It also help school management to 'fish out' defaulting teachers, student teachers and prefects who did not perform in the duties assigned to them.

\section{Movement Book}

This record takes care of the student-teachers movement on each school day. This book contains serial number, name of the student-teacher, date, time left, destination, time expected back and signature. The book helps in locating student teachers in case of emergency. It is a useful document to account for where about of studentteachers, especially during the visit of their supervisors. 


\section{Mentoring Student-teachers on How to Mark and Enter Class Attendance Register}

Class attendance registers are kept for each class in a school. It contains all the names of the students in that class. Boys' names are written first in blue, while the girls' names are written in red. The names are in alphabetical order with the surname first. This record is used to checkmate the students absenteeism and punctuality in daily class attendance.

In addition to students name are columns for fees paid, number in the admission register, age, date of promotion, sex, school fees receipt number, daily and weekly attendances, total number on roll for boys and girls, percentage attendance total attendance for the term, total number of times school opened in the term, and average attendance for the term. The important instructions concerning class attendance register are usually contained on its first page, whereas the instruction on how to mark the register is contained on the last page.

The register is marked twice daily. One at the beginning of the classes in the morning or first session, and the second is at beginning of afternoon session. Attendance is marked with a backward stroke ( ) for the morning session and a forward stroke ( ) for the afternoon session. Absenteeisms are marked (o) for either morning or afternoon sessions. Late attendance is marked with red for any of the sessions. The class teacher or form master should leave the attendance register open for about thirty minutes after roll call to accommodate late comers who would have been erroneously marked absent from school (Onwurah in Mgbodile, 2010).

The class attendance register is to be closed at the end of each school day, week and finally at the end of every term. Summary of attendance is checked and entered at the bottom of the register sheet for each session, or day at the right hand side under weekly totals for each students attendance for the week. This register is to be submitted to the school head or any person delegated by him/her to do the job, for checking at the end of every school week. At the end of every term, a summary of all attendances is to be made and submitted to the school head for checking. It is worth nothing that every class teacher or form master are to submit class attendance register of their class to the school head or whoever he/she assigned the responsibility to on daily basis for safe keeping.

Also the class teacher or form master is required to work out the percentage attendance of class register for the week and for the year, percentage attendance is calculated as:

\section{Attendance multiply by one hundred and divide by expected attendance. Thus:

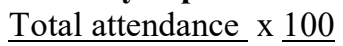 \\ Expected Attendance}

By total attendance we mean the actual attendance and expected attendance means the highest possible attendance for the period, 100 is the percentage. For instance, if the school was opened for only 3 days or 6 sessions during the week due to public holidays or mid-term break or some other reasons, then the expected attendance is calculated as: Total number of the students on roll x 6 . For the normal week it is total number of students $\mathrm{x} 10$, as there are 2 attendances for each day from Monday to Friday.

Therefore, in a class of 30, for an interrupted or disturbed week of 6 session (or 3 days) only, the percentage attendance becomes

$$
\frac{\text { Total attendance }}{30 \times 6} \times \underline{100}
$$

In a normal week of 10 sessions, the percentage attendance becomes total attendance $\mathrm{x} \underline{100}$

$$
30 \times 10
$$

The essence of the percentage attendance is for the teacher, school-head, supervisors/inspectors to have at a glance the level of absenteeism or regularity of students attendance in a class.

Class attendance register should be honestly marked and entered. The idea or habit of class teacher marking the attendance register whenever they like or asking the class prefect or monitor to come to their house to mark the register should be discarded, because it is unprofessional, unethical, negligence of duty, dishonest and dangerous. By such habit, a truant student who had actually been absent from the school may be marked present. If on the process something happened to him and he became missing from home on the day he was actually absent from school, but was marked present, the class teacher could be held responsible to account for the student where about. Besides, such a teacher had falsified official records, which is an indicative of professional misconduct. Therefore, the school-head or whoever may be acting on his behalf should regularly supervised and cross-check the class attendance register.

\section{Mentoring student Teachers on how to enter scheme of work}

Scheme of work is a breakdown of the contents of the syllabus into terms and weeks, subject by subject. In most cases the scheme follows closely a chosen course book or text book out of the list approved by the Ministry of Education or any examining body (WAEC, NECO etc) as adequately covering the syllabus.

In primary schools, the scheme of work is usually prepared by the sectional head or by other staff under his 
supervision. In secondary schools, it is usually prepared by the subject head (that is senior master in- charge of a subject for the whole school) or by other staff under his supervision.

In preparing scheme of work, the teacher to whom it may concerned will look at the subject which he wants to prepare on the syllabus. He will divide the subject into three parts according to the three terms in a year, taking into consideration the length of each terms, and topics most appropriate for particular seasons or periods in the year. For example, in agricultural science, topics such as planting of crops should by taught during planting and rainy season, and crop harvesting should be by harvesting and dry season. In subject like Islam Religious Studies (IRS), topic, like the birth of Mohammed should be taught during the Idi-fit and in Christian Religious Knowledge (CRK) the topic on the death and resurrection of Jeus Christ should be taught during the Holy or Easter season.

After the division of the syllabus into three, the teacher concerned will divide each term into weekly units based on the number of weeks in each term. He will also make provision for revision, examination and closing for the term. Below is an illustration of a format of class three of Junior Secondary School on English Studies.

Figure 11.1: illustration of Scheme of Work

Scheme of Work on English Studies for First term.

Weeks

Contents

\begin{tabular}{|c|c|c|c|}
\hline 1 & $\mathrm{I}$ & Speech sound: & Vowel/e/: \\
\hline 2. & Ii & Comprehension: & The block bush \\
\hline \multirow[t]{2}{*}{2} & I & Language structure: & Question tags \\
\hline & $\mathrm{Ii}$ & Guided composition & The football match \\
\hline \multirow[t]{2}{*}{3} & $\mathrm{I}$ & Speech sound: & The diphithong/ei/; \\
\hline & ii & Comprehension: & The encounter \\
\hline \multirow[t]{2}{*}{4} & $\mathrm{I}$ & Language structure: & Adjectives and adverbs \\
\hline & ii & Guided composition & A traditional Ruler \\
\hline \multirow[t]{2}{*}{5} & I & Speech sound: & The diphithong/ai/: \\
\hline & $\mathrm{Ii}$ & Comprehension: & The Baptism \\
\hline \multirow[t]{2}{*}{6} & $\mathrm{I}$ & Language structure: & Phrases and clauses \\
\hline & $\mathrm{Ii}$ & Guided composition & Argumentation \\
\hline \multirow[t]{2}{*}{7} & $\mathrm{I}$ & Speech sound: & The diphithong/>i/ \\
\hline & $\mathrm{Ii}$ & Comprehension: & Peom IF \\
\hline \multirow[t]{2}{*}{8} & $\mathrm{I}$ & Language structure: & Expressing future Actions \\
\hline & $\mathrm{Ii}$ & Guided composition: & My plans for today \\
\hline \multirow[t]{2}{*}{9} & $\mathrm{i}$ & Speech sound: & The diphithong /au/, \\
\hline & $\mathrm{Ii}$ & Comprehension: & The initiation \\
\hline
\end{tabular}

10-11 Revision

12-13 Examination

14 Closing Activities and Closure 


\section{Second Term}

Weeks

$$
\text { Contents }
$$

\begin{tabular}{l|l|l|}
\hline 1 & I & Speech sound:
\end{tabular}

\begin{tabular}{|l|l|l|l}
\hline 2. & Ii & Comprehension: & The Diphthong /e
\end{tabular}

\begin{tabular}{|c|c|c|c|}
\hline 2. & Ii & Comprehension: & The accusation \\
\hline 2 & I & Language structure: & Expressing past habits and necessity \\
\hline & Ii & Guided composition & My primary school habits \\
\hline
\end{tabular}

\begin{tabular}{|c|c|c|c|}
\hline & & & \\
\hline 3 & I & Speech sound: & The diphithong/ie/; \\
\hline & $\mathrm{Ii}$ & Comprehension: & Taking the case to God \\
\hline \multirow[t]{2}{*}{4} & I & Language structure: & Adjectives and adverbs \\
\hline & $\mathrm{Ii}$ & Guided composition & A traditional Ruler \\
\hline \multirow[t]{2}{*}{5} & $\mathrm{i}$ & Speech sound: & The diphithong/a/: \\
\hline & ii & Comprehension: & The Daniel Jazz \\
\hline \multirow[t]{2}{*}{6} & $\mathrm{i}$ & Language structure: & Asking and given permission \\
\hline & ii & Guided composition & A letter of permission \\
\hline \multirow[t]{2}{*}{7} & $\mathrm{I}$ & Speech sound: & The diphithong/æ/ \\
\hline & ii & Comprehension: & The bond \\
\hline \multirow[t]{2}{*}{8} & $\overline{\mathrm{i}}$ & Language structure: & Expression obligation \\
\hline & $\mathrm{Ii}$ & Guided composition: & My duty to my country \\
\hline \multirow[t]{2}{*}{9} & $\mathrm{I}$ & Speech sound: & The linking "r" \\
\hline & $\mathrm{Ii}$ & Comprehension: & Scanning \\
\hline
\end{tabular}

10 Revision

11 Examination

12 Closure 
Third Term

\section{Weeks Contents}

\begin{tabular}{|c|c|c|c|}
\hline 1 & $\mathrm{I}$ & Speech sound: & Consonant cluster (1) \\
\hline 2. & $\mathrm{Ii}$ & Comprehension: & Noise \\
\hline \multirow[t]{2}{*}{2} & I & Language structure: & Expressing possibility \\
\hline & $\mathrm{Ii}$ & Guided composition & My New school year \\
\hline \multirow[t]{2}{*}{3} & I & Speech sound: & Consonant cluster (2) \\
\hline & ii & Comprehension: & A heaven's door and a voice from the dead (poems) \\
\hline \multirow[t]{2}{*}{4} & $\mathrm{I}$ & Language structure: & Expressing probability \\
\hline & $\mathrm{Ii}$ & Guided sound: & My school farm \\
\hline \multirow[t]{2}{*}{5} & $\mathrm{i}$ & Speech sound: & Consonant cluster (3) \\
\hline & ii & Comprehension: & Nigeria \\
\hline \multirow[t]{2}{*}{6} & $\mathrm{i}$ & Language structure: & Active and passive voice \\
\hline & ii & Guided composition & Reporting and experiment in the laboratory \\
\hline \multirow[t]{2}{*}{7} & $\mathrm{I}$ & Speech sound: & Consonant cluster (4) \\
\hline & $\mathrm{Ii}$ & Comprehension: & Living things \\
\hline \multirow[t]{2}{*}{8} & $\mathrm{I}$ & Language structure: & Direct and indirect speech \\
\hline & $\mathrm{Ii}$ & Guided composition: & Reporting an accident \\
\hline \multirow[t]{2}{*}{9} & I & Speech sound: & vowels in unstressed syllabus \\
\hline & $\mathrm{Ii}$ & Comprehension: & Life on other planets \\
\hline \multirow[t]{2}{*}{10} & $\mathrm{I}$ & Language structure: & Compound sentence \\
\hline & $\mathrm{Ii}$ & Guided composition & A memorable day at school \\
\hline \multirow[t]{2}{*}{11} & $\mathrm{I}$ & Speech sound & Shifting stress \\
\hline & $\mathrm{Ii}$ & Comprehension & MAAMA \\
\hline
\end{tabular}

12 Revision

13 Examination and closure

The above illustrations depicts the scheme of work as the total amount of work to be covered in a year by a class, divided into three according to the three terms in a year, and further divided on weekly basis according to the number of weeks in a term, making allowance for periods to be taken up by revision, examination and closing.

It should be noted that the preparation of scheme of work should be done in advance of the commencement of the new school year.

Mentoring Student-teachers on the use of Diary: Diary is the record of work actually done, period by period or week by week. In other words, diary is the end of weekly entries of units of work completed during the week. Diary is also called weekly record of work. The difference between scheme of work and diary is that the scheme of work is an outline or plan of work to be done while diary is the record of work that has been completed. Therefore, the diary is drawn from the scheme of work. That is the scheme of work is transferred into diary every week only when the topic have been taught.

In primary school, scheme of work is entered accordingly by the class teacher in the class diary, while in post primary schools, the scheme of work is entered by the subject teacher into diary. This is so because in primary schools, there are class teacher teaching all the subjects on the time table in the class, and in post primary schools there are subject teachers, teaching their specialized subjects in several classes of the school.

The diary contains the list of subjects and how the subjects are taught weekly. It also contains below the list of books used in the school, examination results and head teachers report, and notes/principal's initial and date. Below is an example of specimen of weekly record of work.

Fig 11.2: specimen of Weekly Record of Work

Weekly Record of Work

Subject $8^{\text {th }}$ Week Ending 


\begin{tabular}{l}
\multicolumn{2}{l}{ Subject } \\
\begin{tabular}{|l|l|}
\hline English Studies & $\begin{array}{l}\text { Language structure: Adjectives and verbs guided } \\
\text { composition: A traditional ruler }\end{array}$ \\
\hline Mathematics & Whole Numbers: Expression involving brackets and fractions \\
\hline Agricultural Science & Human Activities that effect the forest \\
\hline Basic Technology & Production of metals \\
\hline Basic Science & $\begin{array}{l}\text { Bush burning:causes effects and regulations against bush } \\
\text { burning }\end{array}$ \\
\hline Business studies & Store/stock record \\
\hline Civic education etc & National population census \\
\hline Weekly records of work & \\
\hline List of books used in the schools & \\
\hline Examination result \& Head \& Teacher's reports & \\
\hline
\end{tabular}
\end{tabular}

\section{Notes/Principal's initial \& date}

Student-teachers or in-service teachers should ensure that only work actually completed are entered in the record of work. In other hand, if a teacher record the work he has not completed, such a teacher has exhibited dishonesty and professional misconduct which is misleading and dangerous.

It will be misleading and dangerous in the sense that such a teacher who entered work he has not complete in the diary may go on transfer and/or the subject reassigned to another teacher, the knew teacher will not know that the things recorded by his predecessor is incorrect and may start teaching and set examination questions based on what he saw in the diary, moreso, examinations are set base on what have been taught. Therefore it is advisable that the school head or any person he may delegate to cross check teachers' record of work, should counter check them with students note books.

\section{Mentoring on Extra-Curricular Activities}

Hornby (2000) defined ex-tra-curricular as those activities which is not part of the usual course of work or studies at a school or college. Exeocha (1985) refers to extra-curricular activities as those activities sponsored and organized by students; organizations, educational institutions, and intended to entertain, instruct or provide exercise of various interests and abilities.

From the above definitions it could be deduced that extra-curricular activities are job related activities assigned to the teachers to perform outside the normal official hours which may take place in the evenings, Saturdays and or Sundays. It is those social and recreational clubs and societies or profit or non-profit oriented activities which teachers may or may not be allowed to engage in while still on their job. Such extra-curricular activities expected in the school for students-teachers and even the student-teachers to participate are: games/sports, swimming, dancing, and societies and clubs like Boys bridgade, Boys' scout movement, girls guides, musical society, dramatic and debating society, geographical society, science society, historical society, Nigerian association of future Teachers, Young farmers' club mathematics club etc.

Student - Teacher taking part in extra-curricular activities has a lot of benefits accruable to him. Prominent among them are:

$>$ Development of understanding of human nature and improve the ability to associate comfortably with others either in home or society outside the home.

$>$ Development of worthwhile ideals about culture, fair play, courtesy and cooperative work.

$>$ Learn how to think for themselves, respect for the feelings and views of others, respect dignity of labour and appreciate the values of living usefully within the society as good citizens

$>$ Helping the student teacher in reinforcing classroom learning. For instance, students membership in dramatic and debating society may enhance his/her proficiency in the use of languages. Also, students participating in games and sporting activities are likely to benefit for character training, social and physical development as well as health and mental growth. Similarly, student membership in red cross society enables him/her improve their health.

The above is confirmed by Ukeje, Akabogu and Ndu (1992) when they stated that:

Extra-curricular activities stimulate the youth to explore potential talents and develop vacation skills and interest in a way that regular curricular activities or programmes would not likely to do. They may also offer opportunities to pursue learning beyond that provided in a regular class.

Therefore, student-teachers are encouraged to participate in extra-curricular activities in order to realize some of the objectives of teaching practice exercise. 


\section{Conclusion}

It has been stated that school record and record keeping are indispensable school supportive service which every school personnel must know and keep. Trainee teachers are also included to practically know and keep record which was theoretically taught to them by their mother institution. There were specific types of records which student - teachers are expected to keep during the teaching practice exercise. Such records are national policy on education, syllabus, weekly diary, student-teachers attendance book, student-teacher class attendance book, lesson note and plans, time table, record of student test and assignments, duty roaster and report books and movement books. Also, student-teachers are mentored on their need to involve in extra-curricular activities of the school which a good number of them thought that it is only for "Traditional Teachers".

It is, however, recommended here that:

1. Colleges of education, faculty of education or university colleges should as a matter of fact, integrate record keeping as part of teaching practice practicum just as micro-teaching.

2. School records and record keeping should form part of the things required to is supervised when their supervisors visit them. This will earn the student-teacher the opportunity to integrate easily in recording keeping when they gain employment after graduation and avoid them from embarrassment.

3. The school head of where student-teachers are posted should organize orientation programme for the teacher trainees. One of the topic for discussion should be on school records and record keeping. This will help them (student-teacher) to be aware of the task ahead.

4. Student-teachers should be included in Student Industrial Work Experience Scheme (SIWES). So that teaching practice will be more structured, coordinated and supervised.

5. There should be improved conditions of service and incentives for teachers so that they will be motivate and the teaching profession will be more attractive.

6. Knowledge of school records and record keeping should be taken as one of the utmost criteria for registration of teachers into teaching profession by the Teachers' Registration Council of Nigeria (TRCN) so that student-teachers will know how importance school records and record keeping is in the teaching profession.

7. Tertiary institutions should ensure that students admitted for Post graduate Diploma in Education (PGDE) programme undergo teaching practice exercise so that they will have knowledge of school records and record keeping.

\section{References}

Agina-Obu, T.N. (2009).Teaching practice: A vital phase of teacher education, In L.I. Ajoku (ed) Teaching Practice handbook, Port Harcourt: Pearls Publishers, (33-42)

Agunwa, C.O. (1986).. School records for effective administration, Enugu: mentina.

Asogwa, G.E. (2004). Library records and maintenance. The Nigeria Link 11,(1),88-93

Boash, H.O.N.(1997). Record keeping in Nigeria schools, in A.N. Ndu, L.O. Ocho \& B.S. Okeke (eds)Dynamics of Educational and Administration and management. The Nigerian perspective. Awka: Meks Publishers, 271-285

Ezeocha, P.A. (1985).School management and supervision, Owerri: New African publishing.

Ezewu, E.E.Okoye, N.N. \& Onyekwuelu, V.C. (1984).Student Teacher's Handbook for Teaching practice Port Harcourt: Atariede Publishers.

Horby, A.S. (2000). Oxford advanced learner's dictionary of current English (6th ed), Oxford: University Press.

Igwe, S.O. (1990).Professional handbooks for teachers, Owerri: New African Publishing.

Ochai, G.(2012). The scope of Educational administration, Makurdi: Success words Publications.

Ogbonnaya, N.O.(2012).Record keeping in schools, in N.O. Ogbonnaya (ed) Classroom Organization and management:Issues, principles and practices. Nsukka:Meks Publishers, 142-147.

Onwurah, C. (2004).School support services in T.O. Mgbodile (ed) Fundamentals in Educational Administration and planning Enugu: Magret, 244-258.

Umeji, A.U. \& Obi, C.A. (2013).Record keeping and inventory control skills needs of small business operations in Anambra State International Journal of Educational Research 12(2) 312-328.

Wali, W.I. (2007).A handbook of contemporary issues on education in Nigeria. Port Harcourt: Pearl Publishers. 